EGU Stephan Mueller Special Publication Series, 2, 123-138, 2002

(C) European Geosciences Union 2002

\title{
The late Paleozoic to Cainozoic intraplate deformation in North Arabia: a responce to plate boundary-forces
}

\author{
V. G. Kazmin \\ Institute of Oceanology RAS, Nakhimovsky Prosp., 36, 117851, Moscow, Russia (Email: vkazmin@geo.sio.rssi.ru)
}

Received: 2000 - Revised: 2002 - Accepted: 2002

\begin{abstract}
Several stages of intraplate deformation are distinguished in North Arabia from the Late Paleozoic to Cainozoic. The major rifting episodes occured in the Late Carboniferous-Permian, Middle-Late Triassic and at the end of the Early Cretaceous. None of them shows clear connection with plume activity. The first event correlates with the rifting of several microcontinents from the Gondwana passive margin and the origin of the Neotethyan spreading center. It is speculated that it happend when the Paleotethyan ridge was subducted and the slab-pull was directly transmitted from the active margin to Gondwana. Triassic rifting in North Arabia (probably 2-stage) is related to rifting and transition to spreading in Mesogea. Extension ceased on the Gondwana margin when new spreading axes were formed in Neotethys and Mesogea in the Permian and Late Triassic (?) respectively. Early Cretaceous rifting coincided with formation of the south-facing Peri-Arabian trench system. Again the slab pull was a possible source of extension. Collision of the Arabian passive margin with the trench system and immature island arcs culminated in ophiolite obduction in the Campanian-Early Maastrichtian. This event correlates with the 1st phase of inversion in the North Arabian rift basins and in North Sinai (formation of the Syrian arc). Later stages of inversion correlate with Africa-Eurasia and Arabia-Eurasia collision. To explain simultaneous shortening in the collision zone, compression in the North Arabian rift basins and rifting in the Red Sea and Gulf of Aden in the Oligocene to Pliocene, a numeric model by L. Lobkovsky (1988) is used. According to it, the mantle lithosphere is detached from the crust and continues to subduct through the time of collision. The slab pull creates extension in the lithospheric mantle and rifting along pre-existing "weak zones" (Red Sea), while compression is transmitted at the crustal level to cause inversion of the intraplate basins. It appears that the slab pull is a major force behind all intraplate deformation in North Arabia.
\end{abstract}

\section{Introduction}

Studies of stress-state in intraplate regions show that it depends essentially on plate boundary forces (Zoback and Zoback, 1989). However it is uncertain whether the stresses transmitted from plate boundaries are sufficient to produce thinning of the continental lithosphere and rifting.

There are several examples of the direct links between compressional and wrench-dominated intraplate deformation and collisions at plate boundaries. The best documented cases are the alpine deformation of the European foreland (Illies, 1975; Ziegler, 1990) and the Cainozoic defomation of southeast Asia caused by the India-Eurasia collision (Molnar and Tapponier, 1975; Zonenshain and Savostin, 1981). The situation with intraplate rifting is less clear. Continental rifts, including those which become sites of continental breakup, originate as intraplate structures. The mechanism of their origin is still debated. Are rifts (or at least some of them) "active", i.e. formed above a local energy source usually referred to as a mantle plume, or do they evolve "passively" as a responce to the remote plate boundary-forces? Both points of view have their "pros and cons". Active plume-related rifting is usually advocated on the grounds of the close spatial and temporal relationships between flood basalts and triple junctions, formed above the plume head, and continental breakup (Burke and Dewey, 1973; Hooper, 1990; Campbell and Griffits, 1990; Hill, 1991).

A case for "passive" rifting was recently presented by White and McKenzie that rifting and continental breakup may occur without any link to mantle plumes i.e. that hot (plume-related) and cold (unrelated to plume) rifts are equally likely, but differ strongly in morphology and scale of volcanic activity.

Close to this view is a compromise model recently suggested by Courtillot et al. (1999), who consider plume activity to be a pre-requisite factor for continental breakup, which 
at the same time, must be allowed by the plate boundaryforces.

A new approach to the problem of intraplate deformation was developed recently. It is based on the detailed correlation of intraplate events with events at the plate boundaries. For the Paleozoic to Cainozoic intraplate deformation of the East European platform this correlation was attempted by Nikishin et al. (1996) and for Africa by Guiraud and Bellon (1996) and Guiraud and Bosworth (1997).

Though physical aspects of the problem (the origin, magnitude and transmission of stresses) are not considered in these works, the high level of correlation itself demonstrates that there is a direct link between intraplate and plate boundary events. However, this type of correlation requires very precise knowledge of the geological history, which is not always available.

The northern part of the Arabian plate provides a good record of intraplate deformation, obtained in course of the regional mapping (Ponikarov et al., 1967, 1968 and others), deep drilling and multichannel seismic profiling (Chaimov et al., 1990; Best et al., 1990; Mc Bride et al., 1990; Al Saad et al., 1992; 1993; Chaimov et al., 1992, 1993; Sawaf et al., 1993; Salel and Seguret, 1994; Brew et al., 1997). At the same time good plate tectonic reconstructions of the adjacent portion of Tethys are available in several comprehensive studies (Dercourt et al., 1986; Robertson et al., 1996; Dercourt et al., 1993; Stampfli and Pillevuit, 1993; Natapov and Kazmin (Eds.), 1998). This makes it possible to make a precise correlation between intraplate deformation and events at the plate boundaries. For some cases, simplified schemes are suggested to explain dynamics of interaction between the intraplate and plate boundary processes.

\section{Late Paleozoic-Mesozoic rifts}

Most prominent rift-related structures of Arabia are inverted intracontinental rifts or aulacogenes; e.g. the Palmyrides, Sinjar trough and Euphrates and Anah grabens. To this group, the Drouz depression buried beneath the NeogeneQuaternary basalts (Fig. 1) may also belong.

\subsection{Palmyrides}

The up to $90 \mathrm{~km}$ wide fold belt of the Palmyrides extends NE about $400 \mathrm{~km}$ from the Damascus area (Ponikarov et al., 1967, 1968; Geol. map of Syria, 1964; Fig. 1). West of the Al-Furat river, folds and corresponding ridges plunge beneath the Neogene-Quarternary cover. From the Rutbah uplift in the south, the Palmyrides are separated by the South Palmyra fault zone - a series of steep north-dipping reverse faults and associated small amplitude overthrusts. The en echelon arrangement of faults and fault-related asymmetric and overturned folds suggests a left-lateral component along the South Palmyra fault zone (Kopp et al., 1994) which agrees with an available focal mechanism solution (BenMenachem et al., 1976, 1981).
Interpretation of multichannel seismic data suggests flattening of faults at a shallow detachment along Triassic evaporites. Structural disharmony between the folded MesozoicCainozoic sequence and the Paleozoic deposits is well expressed in the western, but disappears in the eastern Palmyrides (Mc Bride et al., 1990; Chaimov et al., 1990; Chaimov et al., 1992).

North of the South Palmyra fault zone the Pre-Mesozoic basement drops sharply from $5000 \mathrm{~m}$ depth on the Rutbah uplift to $10000 \mathrm{~m}$ in the Al-Daww depression in the southern Palmyrides (Brew et al., 1997). In the north the zone of deep Mesozoic-Cainozoic subsidence (southern Palmyrides) is separated from the northern Palmyrides by the Jahr fault, which is expressed on the surface by a chain of discontinuous faults and flexures. Large vertical displacement on this fault is probably accompanied by a sinistral slip of unknown amplitude.

In the northern Palmyrides the Pre-Mesozoic basement occurs at 4000 to $5000 \mathrm{~m}$, close to the basement depth on the adjacent Aleppo high. In contrast to tight linear fold belts separated by wide synclines (depressions) characteristic for the southern Palmyrides, the structure of the northern Palmyrides is simple and consists of a large anticlinorium known as the Bilas block in the west and the Bishri arch in the east. As pointed out by Razvalyaev (1966) and Kozlov et al. (1966), this anticlinorium may represent a continuation of Antilebanon separated from the latter by an undulation of the fold axis in the southern part the Homs depression (Fig. 1).

Drilling in the Palmyrides reveals a long and complex history which started with subsidence in the Permian or Late Carboniferous (Ponikarov et al., 1967; McBride et al., 1990). Marine sediments 500 to $1300 \mathrm{~m}$ thick were deposited in an asymmetric trough with a steep northern and gentle southern margin. The Permian was also a time of subsidence along the future East Mediterranean margin (Garfunkel and Derin, 1984).

The second period of subsidence and sedimentation, possibly induced by a renewed rifting, falls on the Middle and Late Triassic. From the Permian stage of active subsidence this period was separated by a relatively stable interval in the Early Triassic when detrital limestones and black shales about $130 \mathrm{~m}$ thick, were deposited (Ponikarov and Kazmin, 1965). This was followed by accumulation of more than $1500 \mathrm{~m}$ of middle and upper Triassic clastic sediments and evaporites.

According to drilling and seismic data (Mc Bride et al., 1990, Fig. 5), the Triassic basin had symmetric shape with sediments thinning rapidly towards the Rutbah and Aleppo highs.

Sedimentation continued uninterruptedly into the Jurassic, but subsidence presumably slowed down. The lower and middle Jurassic sediments are represented by shallow water carbonates and evaporites while the Upper Jurassic deposits are missing or incomplete in most of the sections due to emergence and erosion at the beginning of the Cretaceous (Ponikarov et al., 1967). The emergence related to a global 


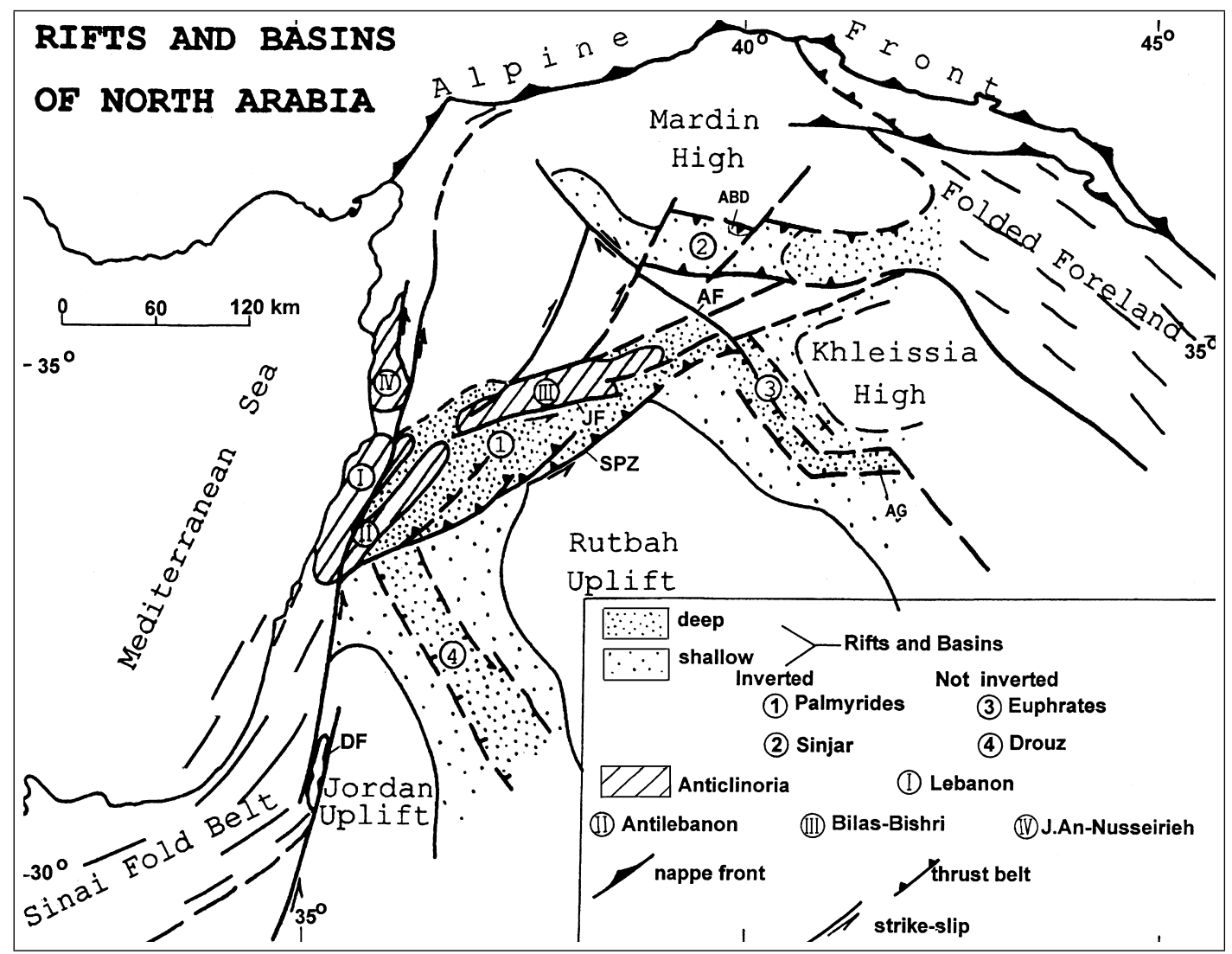

Fig. 1. Rifts and basins of North Arabia. Letter symbols: ABD - Abd El-Aziz anticline; AF - Al-Furat fault; AG - Anah graben; JF - Jahr fault; SPZ - South Palmyra fault zone.

drop of the see level involved most of North Arabia (Murris, 1980).

Neocomian-Aptian, red beds in the Palmyrides were followed by a new transgresive cycle commenced there in the Late Albian. Normal faulting and local basaltic eruptions clearly indicate a tensional regime. By most authors the Late Albian extension is viewed as a major rifting episode which finally formed the Palmyrides rift or aulacogene (Ponikarov et al., 1967; Lovelock, 1984; Chaimov et al., 1992). During the postrift subsidence up to $2500 \mathrm{~m}$ of marine, predominantly carbonate upper Cretaceous and Paleogene sediments accumulated in an asymmetric depression with a very sharp southern and gentle northern slope. Thus the polarity of the rift structure changed.

The overall present-day structure of Palmyrides is a result of the multistage roughly $\mathrm{N}-\mathrm{S}$ compression caused by the Arabia-Eurasia collision during last 50 Ma. In Middle Miocene to Recent time deformation was enhanced by a restricting bend of the Yammuneh fault, the western transform boundary of the Arabian plate (Freund et al., 1970; Kopp et al., 1994 and other). A sinistral transpressional component along the South Palmyra fault zone is probably related to the clockwise rotation of the Rutbah block, which results from a sharp change in the amount of shortening in the Palmyrides from west $(20 \mathrm{~km})$ to east $(1 \mathrm{~km})$ (Chaimov et al., 1990). Extensive field studies show that the main compressional episodes occured in the Campanian - Early Maastrichtian, Middle Eocene-Oligocene; Middle-Late Miocene and Late Pliocene - Quaternary time (Ponikarov et al., 1967, 1968; Faradzhev, 1966; Soulidi-Kondrat'ev, 1966).

\subsection{Sinjar trough}

This is an east-west striking, about $50 \mathrm{~km}$ wide, zone of deep basement subsidence situated in northwestern Iraq and northeastern Syria. Its deepest part, with basement depths more than $9000 \mathrm{~m}$, is in the east (Brew et al., 1997); westward the basement shallows to 3000-4000 m near the Euphrates transcurrent fault (Syria). The basement depression is bounded by faults traced in the gravity field by steep gradients (Galaktionov and Demidov, 1966). A short segment of the northern boundary fault can be seen at the surface along the northern flank of the Abd El-Aziz anticline, where it is a steep southdipping thrust. Presumably the boundary faults were initially normal faults inverted into thrusts during the late MiocenePliocene inversion. The long linear anticline of Sinjar is the most prominent structure in the eastern part of the trough, while in the west the whole of its width is occupied by a broad and very gentle swell formed by Miocene sediments. Besides the fault-related Abd El-Aziz anticline, other second order folds are brachyanticlines.

P. Lovelock (1984) was first to suggest that the Sinjar 
trough has much in common with Palmyrides, though it may be somewhat younger. The main periods of subsidence correspond here to the Middle Triassic and Late Cretaceous (Lovelock, 1984; Sawaf et al., 1993).

First indication of compression is evident in the Abd ElAziz anticline where the Campanian-Maastrichtian beds include an olistostrome with blocks of Carboniferous rocks (Leonov et al., 1986). The reduced section of Paleogene sediments indicates that the anticline began to grow at the end of the Cretaceous.

The Sinjar swell, smaller folds and reversed faults were formed mainly during the late Miocene-Pliocene inversion, which was much less strong here than in Palmyrides.

\subsection{Euphrates graben}

This northwesterly trending feature is buried by NeogeneQuaternary sediments and is known only from seismic reflection surveys and drilling (Ponikarov et al., 1967; Lovelock, 1984; Sawaf et al., 1993; Brew et al., 1997). A number of fault bounded steps bring the basement surface down from the Rutbah uplift margin to a depth of $9000 \mathrm{~m}$ near the Euphrates (or Al-Furat) fault. From the east the graben is bounded by a narrower and steeper slope of the Khleissia high and in the south joins almost at right angles the Anah graben, coinciding with the east-west segment of the Euphrates river. In the northeast the Euphrates graben terminates against the South Palmyra fault zone.

According to P. Lovelock (1984), the oldest sediments in the Euphrates graben are Triassic. However the Thayyem103 drillhole in the northern part of the graben struck Permian beds at the bottom (Sawaf et al., 1993), thus subsidence might have begun at the same time as in the Palmyrides. The second major period of subsidence began in the Late Early Cretaceous, again simultaneously with the Palmyrides. In contrast to the latter, the Euphrates graben has not suffered the Cretaceous and Cainozoic inversions and continued to subside uninterruptedly through the Paleogene and Neogene. The reason of this will be discussed later.

\subsection{Drouz depression}

Situated between the Rutbah and Jordan uplifts is another northwesterly trending and possibly rift-related basin. On the surface the depression is covered by basaltic flows reaching its maximum thickness of about $1500 \mathrm{~m}$ in the Jebel Drouz - a volcanic ridge rising up to $1600 \mathrm{~m}$ above s.l. in the axial zone of the depression. According to drilling data, the base of the basaltic pile beneath the ridge is at $100 \mathrm{~m}$ above s.l., i.e. $400 \mathrm{~m}$ deeper than at the basaltic plateau margins. At the same time the basement depth in the Drouz depression is about $7 \mathrm{~km}$ or more (Brew et al., 1997). This means that the depression is filled by a thick sequence of Paleogene, Cretaceous and possibly older sediments (Ponikarov et al., 1967).

The Early Miocene to Recent basaltic eruptions on the Jebel Drouz and Hauran plateau were controlled by fractures of the northwesterly trend marked by chains of volcanic cones. As in other parts of Arabia, these fractures are most probably re-activated basement faults, which could control subsidence at the rifting stage.

\section{Summary of rift evolution (Fig. 2)}

Following a long period of non-sedimentation or/and erosion, a new sedimentation cycle began in North Arabia in the Late Carboniferous-Permian. In Central Syria, thick succession of clastic and carbonate rocks accumulated in a shallow marine basin centered on the Palmyrides. P. Lovelock (1984) and Y. H. McBride et al. (1990) associated this event with the first stage of rifting in the Palmyrides. Permian sediments are also known in the Euphrates graben (Sawaf et al., 1993) which possibly originated at the same time.

In several deep wells in Syria, including the Palmyrides (e.g. Doubayat - Ponikarov et al., 1967), the contact between Permian and Triassic sediments is marked by an unconformity. The latter is of regional nature and can be traced in the adjacent areas of Arabia and Sinai. According to F. Hirsh (1990), most of the Lower Triassic section is missing in northern Sinai within a fold belt known as the Syrian arc. The gap is attributed to a global drop of sea level.

Subsidence renewed in Palmyrides at the end of the Early Triassic and continued through the Middle Triassic. P. Lovelock (1984) argued that the Sinjar trough began to subside in the Middle Triassic. In a deep well Syrom-2 within the trough (see the transect across eastern Syria-Sawaf et al., 1993), Triassic strata overlie directly Silurian rocks. However in other wells (e.g. Aba and Tueman - see sections in Ponikarov et al., 1967) Triassic sediments are shown to rest unconformably on Permian or Carboniferous-Permian rocks. Thus the earlier than Triassic origin of the trough can not be so far excluded.

In the Euphrates graben lower and middle Triassic sediments are absent but very considerable subsidence occured in the Late Triassic (Sawaf et al., 1993). It is possible therefore that in the Syrian rifts there were two different Triassic stages of extension and rifting: in the late Early Triassic and in the Late Triassic. It is important that a new sedimentation cycle began in the late Early Triassic in the eastern Mediterranean near-coastal areas. This event was alternatively attributed either to oscillations of the sea level (Hirsh, 1990) or to formation of the Levantine passive margin, which was finally formed in the Late Triassic (e.g. Sengor, Yilmaz, 1981; Garfunkel and Derin, 1984).

The major rifting epizode in all North Arabian rifts occured in the late Early Cretaceous. It followed a period of emergence and erosion in the Neocomian and was followed, in its turn, by postrift subsidence in the Late Cretaceous. Rifting was accompanied by eruptions of basalts in Syria, Lebanon and Israel. As seen from distribution of thicknesses of the Cretaceous sediments (Ponikarov et al., 1967) the Palmyra boundary faults were finally shaped at that time. Faulting was also active in the Sinjar trough and the Euphrates graben (Lovelock, 1984). 
CORRELATION OF EVENTS IN THE NORTH ARABIAN RIFT BASINS

AND TETHYS OCEAN

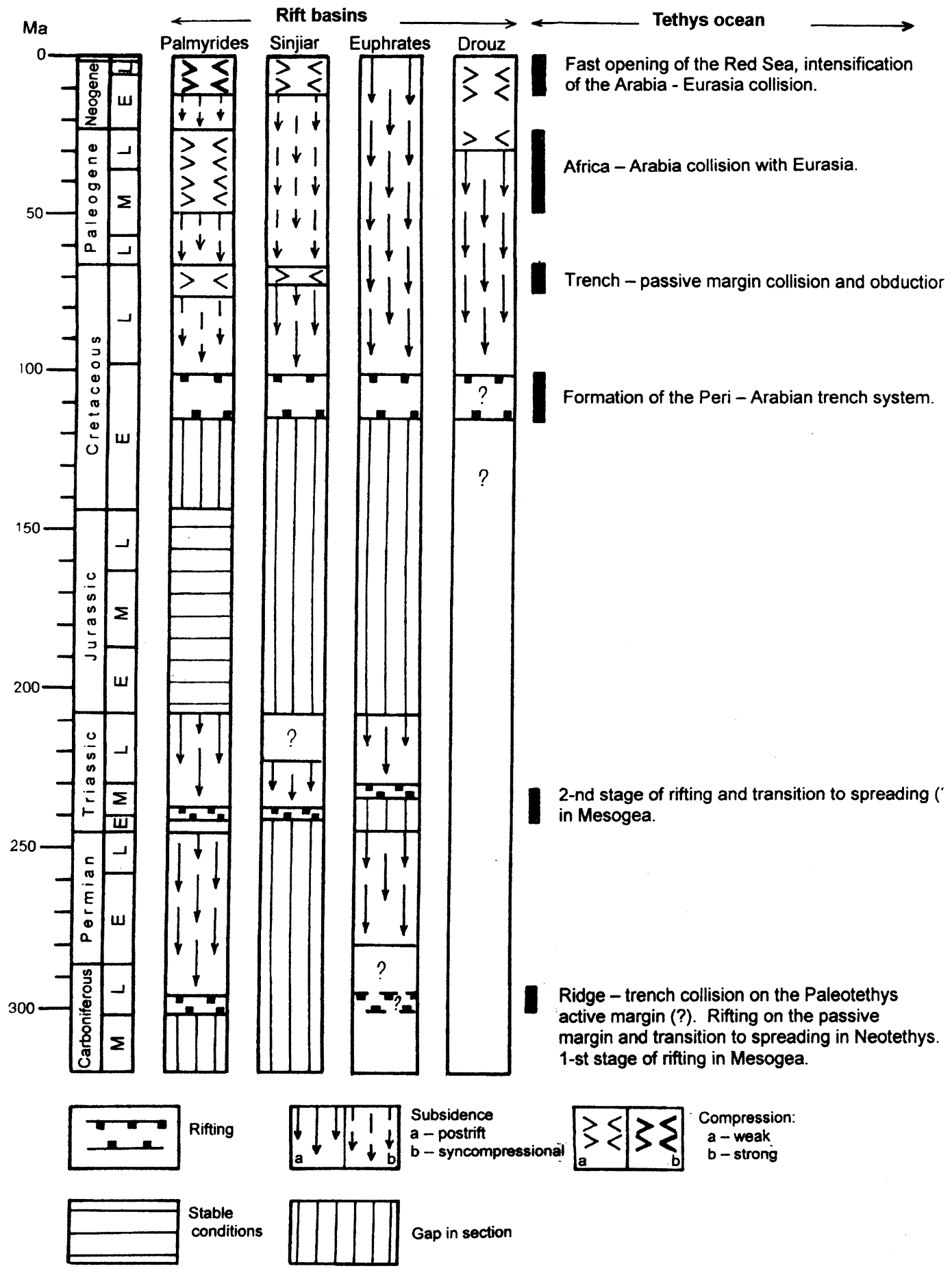

Fig. 2. Correlation of events in the North Arabian rift basins and the Tethys ocean.

The first manifestation of compression in the Late Senoman - Early Maastrichtian is documented in the Palmyrides and in the Sinjar trough. In both rift basins gentle folding resulted in complex variation of thickness and facies of the Paleogene deposits: reduced and incomplete sec- tions characterise cores of anticlines while in synclines sedimentation was uninterrupted (Faradzhev, 1966; SoulidiKondratiev, 1966). Formation of the Campanian olistostrome observed in the Abd El-Aziz anticline (Leonov et al., 1986) was probably associated with reverse faulting and overthrust- 


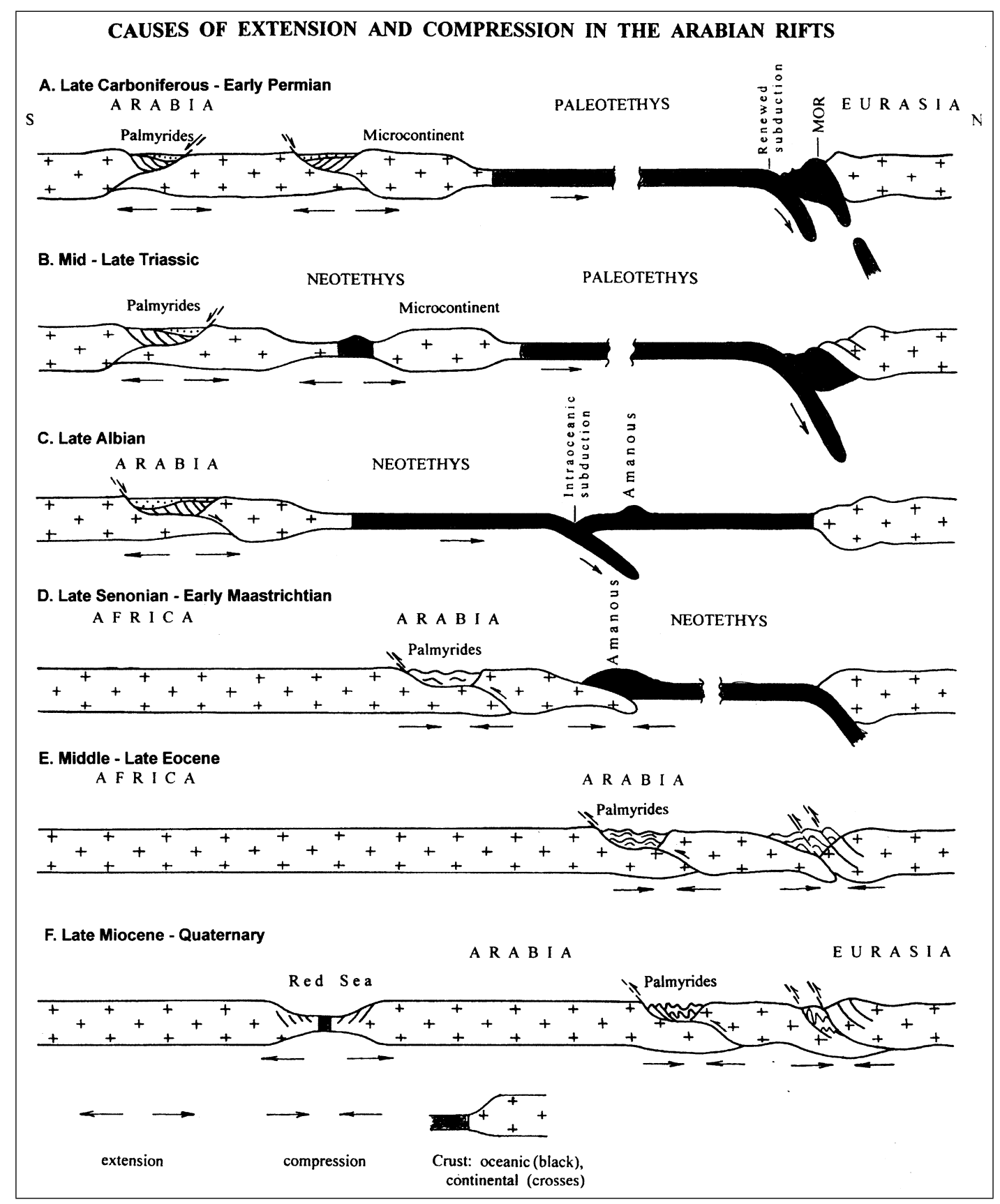

Fig. 3. Causes of extension and compression in the Arabian rifts.

ing along the marginal faults of the Sinjar trough. Deformation was even more conspicuous in northern Sinai where folds of the Syrian arc were formed (Hirsh, 1990).

Several compressional pulses occured in North Arabia during the Middle Eocene to Oligocene interval. Of the North Arabian rifts, the Palmyrides were most affected. Growth of anticlines and associated uplifts continued here up to the end of the Oligocene, when the sea retreated finally from the area. In the Sinjar trough Eocene deformation is poorly documented and in any case was much weaker than in Palmyrides. The marine basin persisted here through the Oligocene and only in the Aquitanian was it briefly in- terrupted (Galaktionov and Demidov, 1966; Ponomarev and Bivshev, 1966). There is no indication of Paleogene compression in the Euphrates graben and Drouz depression.

Compressional events in Middle-Late Miocene and Pliocene-Quaternary time created the present-day structure and geomorphology of the Palmyrides: a system of linear ridges (anticlines) and intermontane depressions (synclines). Underthrusting of the Rutbah uplift led to transformation of normal faults into steep reverse faults and overthrusts and to the formation of decollement along the Triassic evaporite horizon. Compression and shortening were strongest in the west (near Antilebanon) and reduce drastically eastward 

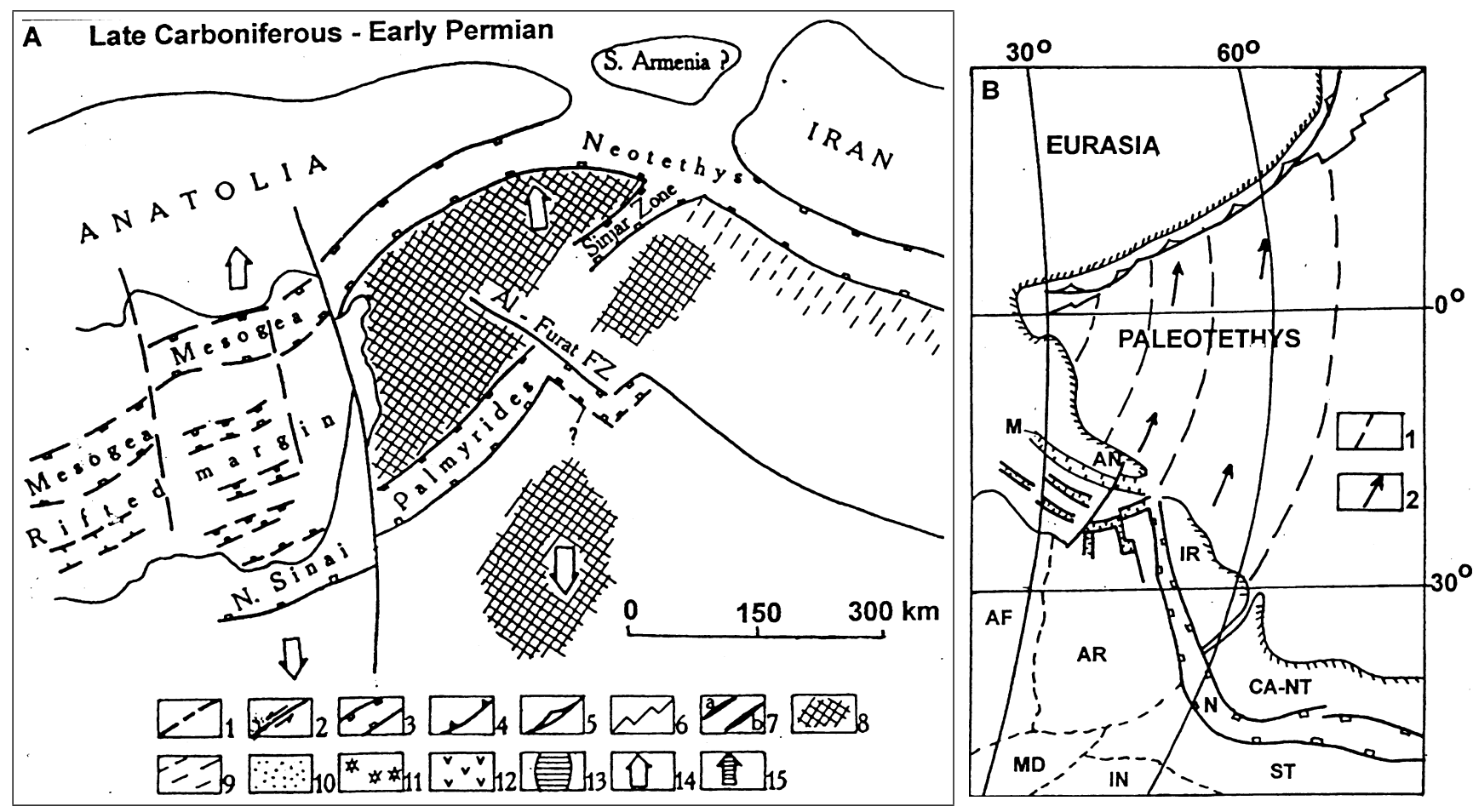

Fig. 4. (a)Paleotectonic scheme for Late Carboniferous - Early Permian time. 1st tensional stage. 1 - fault; 2 - strike-slip fault; 3 - normal fault; 4 - nappe front, overthrust; 5 - subduction; 6 - spreading center; 7 - folding: a - weak; $\mathrm{b}$ - strong; 8 - uplift; 9 - subsiding margin; 10 - foredeep; 11 - volcanic arc; 12 - basalts; 13 - fault-related large antiforms; 14 - hypothetical direction of the deformation axis based on major structural features; 15 - Arabia/Eurasia relative motion vector. COB-continent-ocean boundary; T - Troodos; B - Baer-Bassit; DD Drouz depression; ED - Euphrates graben (depression). (b) Late Carboniferous - Early Permian position of the North Arabia rifts on the Paleotethyan margin. Reconstruction of Paleotethys after J. Golonka (2000) with modifications. Paleotethyan ridge is being subducted in the Eurasian trench system. Slab pull is transmitted to the passive margin causing rifting. Direction of the slab pull coincides with the inferred vector of the plate convergence. 1. - inferred vector of the plate convergence; 2 - direction of the slab-pull. AR - Arabia; AF - Africa; AN Anatolia; CANT - Central AfganistanNorthern Tibet; IR - Iran; IN - India; M - Mesogea; MD - Madagascar; N - Neotethys; ST - South Tibet.

(Chaimov and Barazangi, 1990). East of the Euphrates fault zone Neogene compression was weak. The Sinjar through was inverted into a broad and flat arch (Ponikarov et al., 1967; Lovelock, 1984) complicated by brachyform anticlines. It is apparent that deformation was caused mainly by the northward movement of the block limited by the Dead Sea and the Euphrates fault zones. Sedimentation and subsidence continued uninterruptedly in the postrift basin above the Euphrates graben and, presumably, in the Drouz depression. Moreover the latter shows clear evidence of extension: open fractures of northwest strike controlled basaltic eruptions through the whole Neogene-Quaternary interval.

\section{Intraplate deformation in North Arabia and plate boundary evolution: an attempt at correlation}

As seen from the above, the history of intraplate deformation in North Arabia is reasonably well studied. At the same time extensive studies have been carried out during last decades to reveal the history of the surrounding oceanic basins as well as the processes at the boundaries of the African and Arabian plates (Sengor, 1979, 1984; Robertson and Woodcock, 1980; Dercourt et al., 1986, 1993; Robertson et al., 1996; Stampfli et al., 1991; Stampfli and Pillevuit, 1993; Knipper and Sharaskin, 1994; Natapov and Kazmin (Eds.), 1998; Le Pichon and Gaulier, 1988, and many others). Now there is a good chance to correlate intraplate and plate boundary events and to demonstrate how the former depend on the latter (Figs. 2 and 3).

\subsection{Late Carboniferous - Permian stage (Figs. 3a and 4)}

The time of the initial rifting in North Arabia (Palmyrides, the Euphrates graben) coincides with fragmentation of the Gondwana margin, separation of several microcontinents from it and the origin of the Neotethyan spreading axis. A deep basin existed north of Oman (De Wever et al., 1988) and south of Iran (Berberian and King, 1981; Cherven, 1986) already in the Permian. According to the G. Stampfli and A. Pillevuit (1993) subsidence curves based on drilling data for the northern African passive margin show a single early 

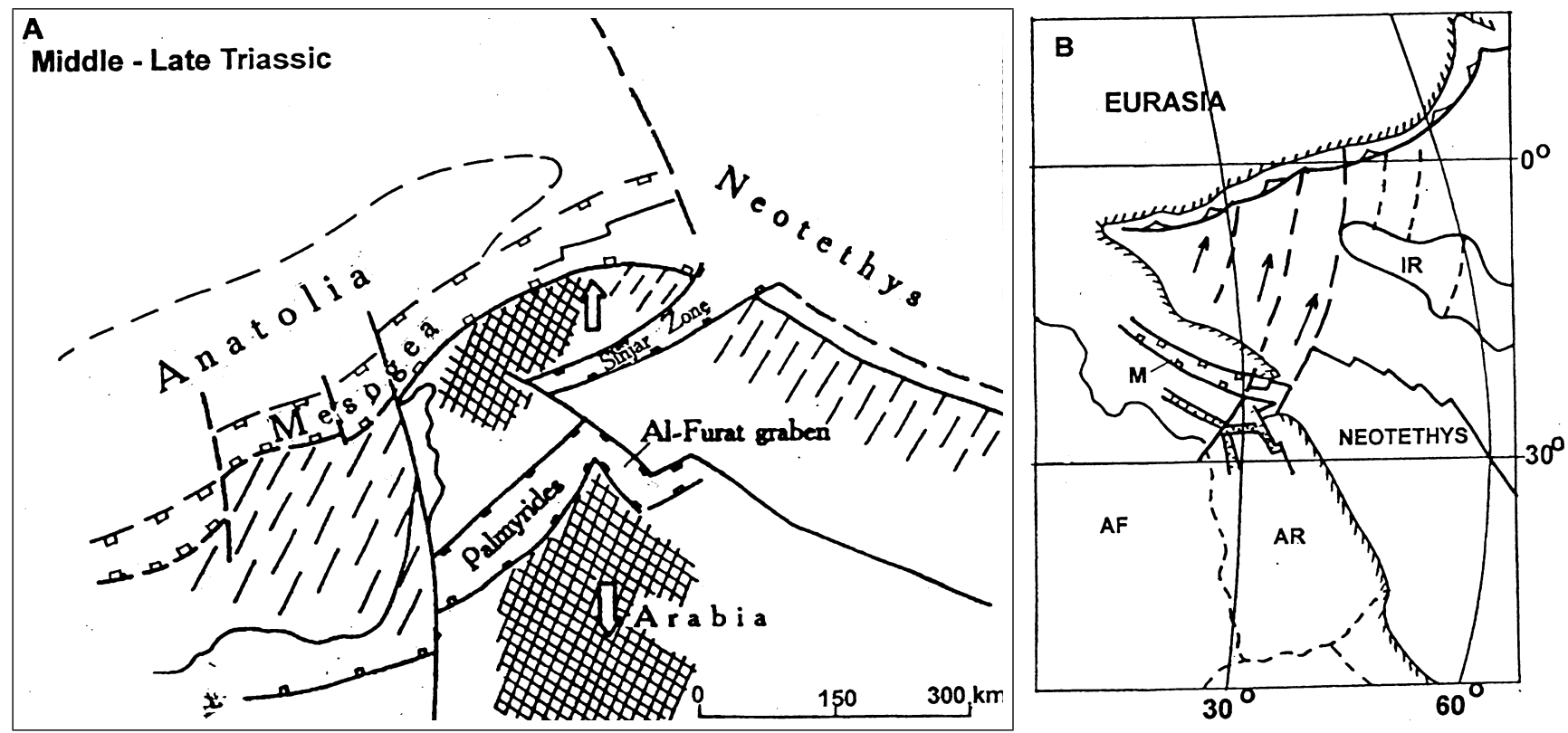

Fig. 5. (a)Paleotectonic scheme for the Mid-Late Triassic. 2nd tensional stage. Symbols in Fig. 4a. (b) Mid-Late Triassic position of North Arabian rifts on the Paleotethyan margin. Reconstruction of Paleotethys by J. Golonka (2000) with modifications. In the eastern part of the ocean, where the Neotethyan spreading center is active, the slab pull is not affecting the passive margin. Still rifting of the margin is in progress in the western part, where the new spreading center had not yet been formed. Symbols as in Fig. $4 \mathrm{~b}$.

Permian rifting event, which, in their opinion, was followed by spreading. Thus the earliest stage of intraplate rifting in Arabia (Fig. 4a) was apparently contemporaneous with the major rifting event on the Gondwana margin.

But what was the cause of rifting? C. Sengor $(1990,1991)$ suggested that rifting occured in a backarc setting behind the north-facing subduction zone. However no CarboniferousPermian suprasubduction magmatism is known on the microcontinents separated at that time from Gondwana (Iran, Afghanistan, Central Pamirs, North Tibet etc.), therefore the backarc mechanism is unlikely. Another hypothesis is proposed here.

In the latest Paleozoic compressional deformation, which can not be accounted for by collisions with microcontinents or island arcs, occured in several places along the active Tethyan margin. This deformation is known for example in the Frontal and Main Ranges of the Caucasus (Belov, 1981), in northeastern Iran (Aghdaraband), where the "Hercynian" deformation preceeded short "epyhercynian" cycle of sedimentation spanning the Late Permian and Triassic (Ruttner, 1984) and probably in the North Pamirs (Shwolman, 1977) and Kunlun (Pan Yusheng, 1996). It is suggested here that deformation was the result of a ridge-trench collision that temporarily blocked subduction (Natapov and Kazmin (Eds.), 1998). In time when subduction was renewed, the active margin and Gondwana were not separated by a spreading axis. This situation is demonstrated in Fig. 4b, which shows position of the North Arabian rifts in the Paleotethyan framework. The trajectories of the relative plate motion were inferred from the initial (pre-drift) and final (collision) position of microcontinents (e.g. Iran, North Tibet). These trajectories coincide or are close to the direction of the slab pull the major plate moving force. Extension created by the slab pull might have been translated in this case to the Gondwana margin. There it could have led to rifting along the ancient sutures or "weak zones". In Palmyrides, for example, rifting most probably followed an old suture between the Rutbah and Aleppo blocks interpreted as terranes accreted in the Late Precambrian to the Gondwana margin (Best et al., 1993; Sawaf et al., 1993; Brew et al., 1997). The stress translation ceased when a new spreading axis was formed.

\subsection{Triassic stage (Figs. $3 \mathrm{~b}$ and 5)}

The Middle-Late Triassic was a time of major rifting and postrift subsidence in North Arabia. This rifting can be correlated with events in eastern Mediterranean or Mesogea. (Fig. 5a). While in Neotethys transition to spreading occured presumably after a single rifting phase in the Early Permian (Stampfly and Pillevuit, 1993; Stampfly and Mosar, 1998), the evolution of Mesogea was probably different. Though the initial rifting here was in the Permian or latest Carboniferous (Stampfli and Mosar, 1998), the transition to spreading might have occured much later after one or two additional rifting phases. The evidence comes from the Mamonia, Godene and Tamima complexes in Cyprus, Antalya (S. Turkey) and Baer-Bassit (NW Syria) respectively (Robertson and Woodcock, 1979; Robertson and Woodcock, 1984; Parrot and Whitechurch, 1978; Knipper and Sharaskin, 
1994). All these complexes represent sediments and volcanics accumulated at the passive margin and in the deep basin of Mesogea. Remarkably they do not contain rocks older than Upper Triassic, which timplies that the oceanic basin of Mesogea did not open prior to this time. Consequently, there was not only the Permian but also the Triassic phase or phases of rifting. Fig. $4 b$ shows differences between the eastern and western Tethyan sectors in the Triassic time. In the east, where Neotethys was rapidly opening, the slab pull was not anymore transmitted to the Gondwana passive margin and rifting here ceased. At the same time in the west the new spreading axis still had not been formed and extension created by the slab pull persisted. The direction of the slab pull (or deformation axis) coincided with the vector of the plate convergence. Rifting continued in North Arabia and North Africa till the Late Triassic, (or earliest Jurassic?) when a new spreading center was formed in Mesogea.

\subsection{Early Cretaceous stage (Figs. 3c and 6)}

All North Arabian rifts were actively subsiding through almost the whole of Late Cretaceous time. This subsidence was preceeded by volcanism associated with the renewal of extension and faulting (Lovelock, 1984). As at the previous stages, SW-NE and NW-SE rifts were simultaneously subjected to extension. Taking into account this and orientation of the Mesogea subduction zone, one can suggest that the deformation axis was close to $\mathrm{N} 160^{\circ} \mathrm{E}$. In this case extension was almost perpendicular to strike of Palmyrides and oblique to strike of the Euphrates graben. In the Tethys ocean the late Early Cretaceous was a period of major plate boundary re-organization. The subduction zone jumped southward from the northern active margin of the ocean to be formed in close proximity to the Arabian passive margin. X. LePichon (see in Dercourt et al., 1986 and Kazmin, 1991b) suggested that the cause of the jump was a ridge-trench collision which blocked subduction of the Tethyan lithosphere. The time of the jump is not precisely established. The peri-Arabian ophiolites, originated in a backarc setting behind the newlyformed trenches, mainly in the Cenomanian or CenomanianTuronian, 95-87 Ma ago (Knipper et al., 1986). In Cyprus, where the ophiolites are covered by the Cenomanian sediments of the Parapedi formation (Irving et al., 1980) their age is probably Pre-Cenomanian. In any case, initiation of subduction in the Peri-Arabian trenches was in the late Early Cretaceous i.e. preceeded ophiolite formation by several millions of years. It coincided, therefore with extension and rifting in North Arabia. Again, as in the previous cases, extension was most probably created by the pull of the sinking slab and transmitted to the continent from the newly-formed plate boundary.

A remaining problem is the possible relationship between the Mesozoic rifting in North Arabia and plume activity. Correlation of magmatic cycles to fragmentation of Gondwana was recently attempted by A. Segev (2000). In Levant he recognizes two magmatic periods related to the superplume activity: Jurassic (205-160 Ma) and Cretaceous (138-83 Ma).

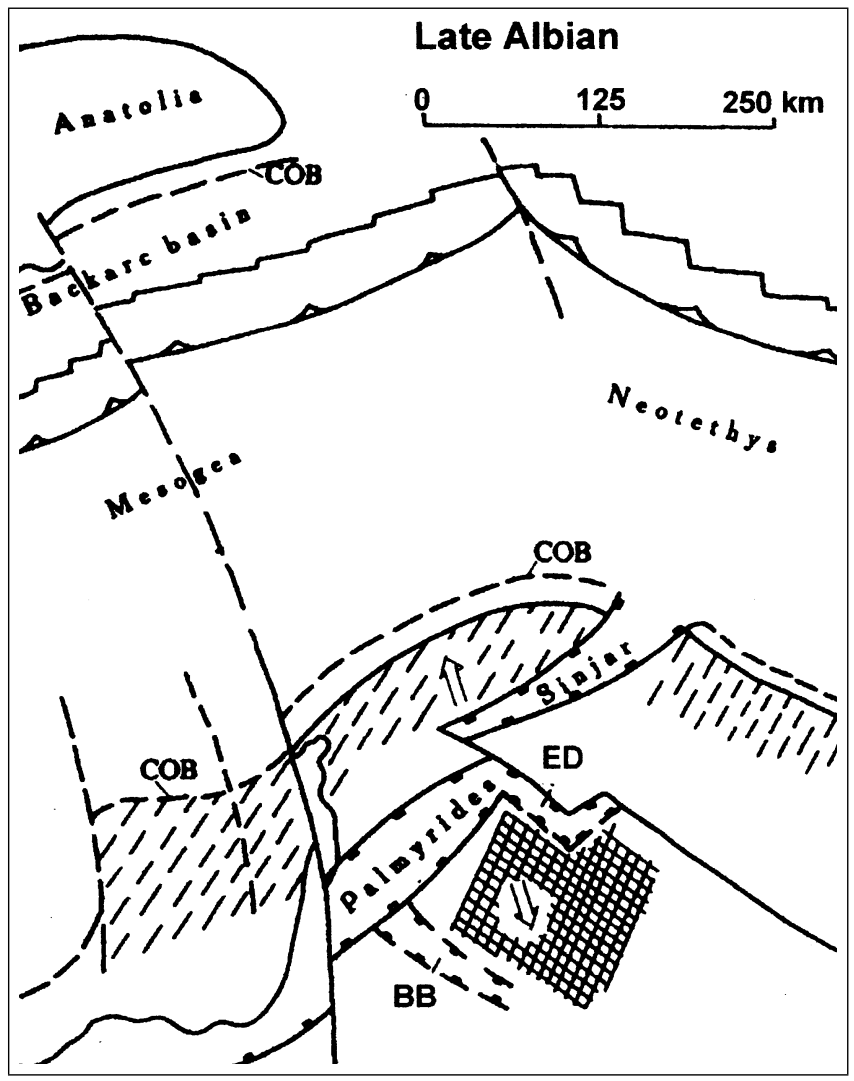

Fig. 6. Paleotectonic scheme for the Late Albian. 3rd tensional stage. Symbols in Fig. 4a.

Jurassic magmatic rocks (basalts, gabbro) occur in Levant very sporadically in the near-coastal areas of Israel and Lebanon. No Jurassic rifting is known either in North Arabia or on the northern margin of Gondwana. In cited work the Jurassic magmatic period "is associated with the opening of Neotethys". However, the Neotethys' opening began in the Early Permian and terminated in the Late Triassic. The Jurassic magmatism was certainly related to the opening of Central Atlantic, but has no tectonic correlation on the northern Tethyan margin, including Arabia.

The Cretaceous "superplume" was manifested in Levant within the "Levant-Nubian province (swell)". Again sporadic magmatic activity occured in a $\mathrm{N}-\mathrm{S}$ elongated oval area parallel to the Mediterranean margin and the Levant fault system (op. cit. Fig. 4). East of this zone magmatism is practically absent. There was no spatial connection between the "swell" and the North Arabian rifts but its structural link with the transform margin of the East Mediterranean basin is very clear. On a broader scale the question is : Is any manifestation of the intraplate magmatism necessarily related to plume activity? Experimental data show that on a limited scale magmatism may accompany "cold rifting" without plume interference, the melt produced by decompression of rising asthenosphere in the extended lithosphere (White and Mc Kenzie, 1989, 1995). There was certainly no Mesozoic LIP (Large igneous province-Coffin and Eldholm, 1991) in North 


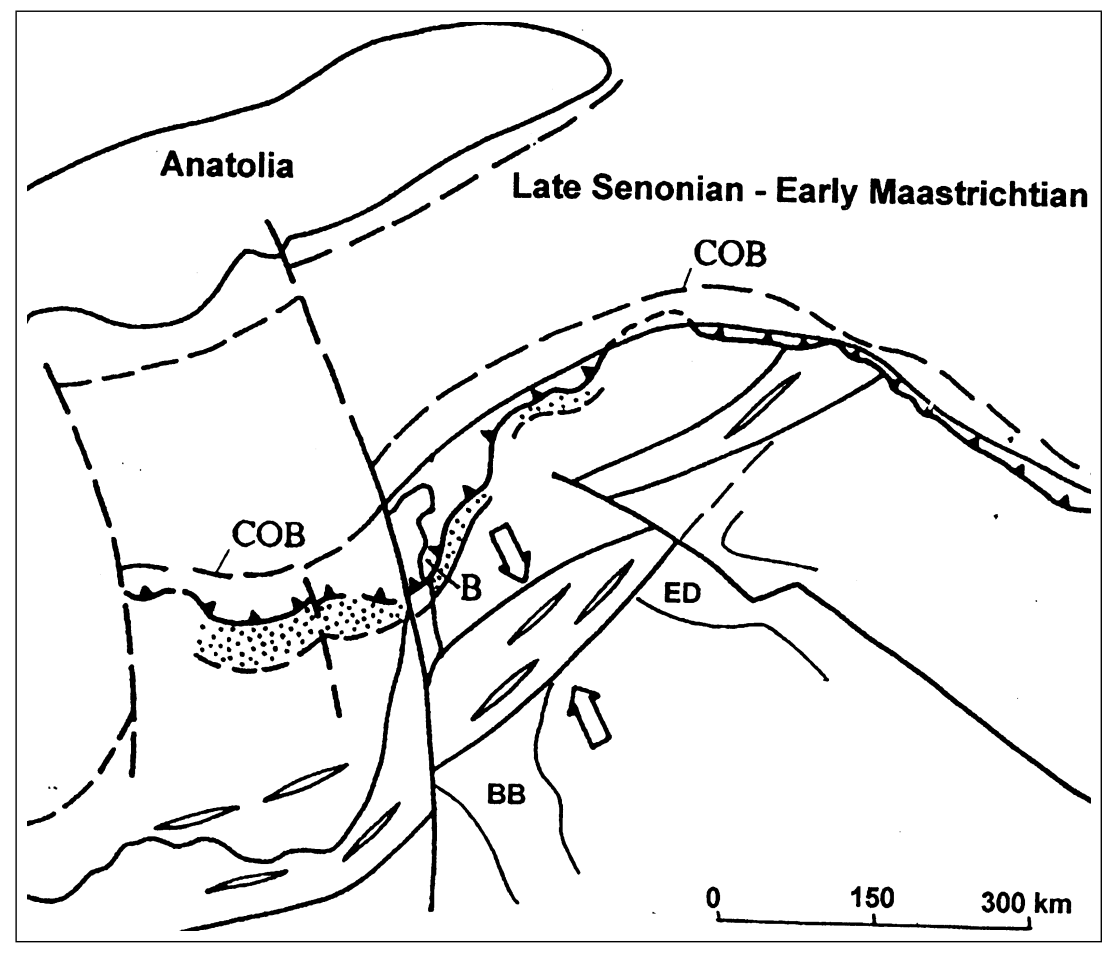

Fig. 7. Paleotectonic scheme for the Late Senonian - Early Maastrichtian. 1st compressional stage associated with ophiolite obduction onto Arabian margin. Symbols in in Fig. 4a.
Arabia indicative of strong thermal perturbation and largescale partial plume-related melting. Volcanic rocks had very modest volume and were mostly alkaline basalts.

On the other hand, the North Arabian rifts were formed at a time of major plate boundary reorganizations which could have caused extension and rifting in the Arabian plate. As discussed above, this causal link was especially clear in the late Early Cretaceous.

\subsection{Late Senonian - Early Maastrichtian stage (Figs. 3d and 7)}

This was the time of compression and folding in the NE-SW trending rifts of North Arabia (Palmyrides, Sinjar) and in the Syrian arc of northern Sinai. There is no evidence of compression in the NW-SE trending rift structures (the Euphrates graben and Drouz depression) which were presumably parallel to the main compressional stress axis.

The cause of compression was collision of the Arabian passive margin with the system of Peri-Arabian trenches, which began in the Late Senonian and terminated with the ophiolite obduction. The latter was diachronous: it occured in the Late Santonian in Oman (Guirand and Bosworth, 1997) and in the Campanian-Early Maastrichtian in southeastern Turkey (Dubertret, 1953; Yazgan, 1984) and in northwestern Syria (Parrot and Whitechurch, 1978; Knipper et al., 1988). In Cyprus formation of the Mammonia accretionary complex terminated also in the Campanian, marking the end of subduction of the Mesogean lithosphere (Robertson and Woodcock, 1979, 1984; Knipper and Sharaskin, 1994; Krylov et al., in press). This was explained as a result of collision of the African passive margin, highly extended in the course of the Permian-Triassic rifting, with a trench located south of Cyprus. (Kazmin, 1991a). The nappe structure of the Mammonia complex was finally formed prior to the Late Maastrichtian (Knipper and Sharaskin, 1994; Krylov et al., in press) synchronously with ophiolite obduction in northwest Arabia. In this way the compression from the collision zone was transmitted not only to the Arabian, but also to the African margin (e.g. folding in the Syrian arc).

R. Guiraud and W. Bosworth (1997) argued that in the Syrian arc and northern Arabia there was a late Santonian compressional episode followed by an extensive phase of rifting in the Campanian - Maastrichtian. In fact the Campanian Early Maastrichtian was a time of compression in the Syrian arc and North Arabian rifts. In the Syrian arc folding was active in the Campanian: after that folds were transgressively overlapped by late (?) Maastrichtian and younger sediments (see Fig. 10 in Hirsh, 1990). Similar relationships were observed in the Palmyrides and Sinjar where compression culminated in the early Maastrichtian (Ponikarov et al., 1967), i.e. simultaneously with the ophiolite obduction on to the Arabian passive margin.

\subsection{Eocene-Oligocene stage (Figs. 3e, 8 and 9)}

The Campanian - Early Maastrichtian compression was followed in the North Arabian rifts by a period of subsidence and quiet sedimentation spanning the Maastrichtian to Early Eocene. This period correlates with the final closure of Neotethys and eastern Mesogea between Arabia and Iran and the Taurides, respectively (Fig. 8). In eastern Mesogea the lithosphere of the late Cretaceous backarc basin was consumed in the Kyrenia trench-arc system situated at the south- 

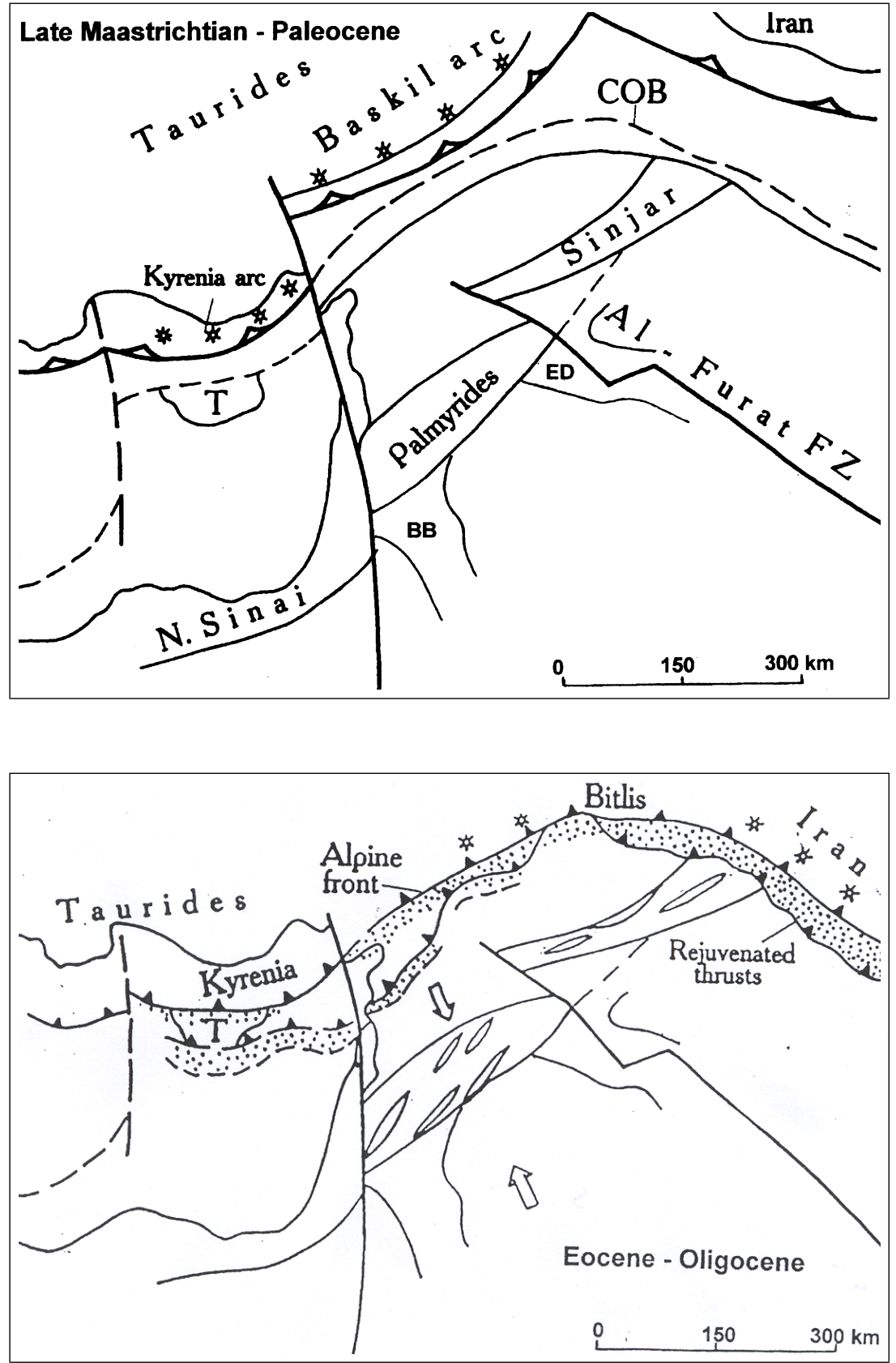

Fig. 8. Paleotectonic scheme for the Late Maastrichtian-Paleocene. Symbols in Fig. 4a.
Fig. 9. Paleotectonic scheme for the Eocene-Oligocene. Arabia-Eurasia collision and related compression. Symbols in Fig. 4 a ern margin of the Taurus carbonate platform. The late Maastrichtian to Eocene arc-type volcanics of Kyrenia (Baroz, 1980; Geol. map of Cyprus, 1979) rest on the Paleozoic to Mesozoic Carbonate platform rifted in the Oligocene (?) from the Taurus platform.

Collision of Arabia with Iran and the Taurides began in the Middle Eocene (Dercourt et al., 1986; 1993; Natapov and Kazmin (Eds.), 1998 and other sources). This event marked the onset of a series of compressional episodes in the Palmyrides (Ponikarov et al., 1967) and LebanonAntilebanon (Hencock and Atiya, 1979). Folding and uplift in the Palmyrides resulted in the final retreat of the sea in the Oligocene. The Eocene-Oligocene deformation was weak or absent in the Sinjar trough and the Syrian arc, which implies some independent movement of the block between the Dead Sea and the Euphrates fault zones (Fig. 9). However, no Eocene to Oligicene displacement on either fault zone has been so far documented.

\subsection{Neogene-Quaternary stage (Figs. 3f, 10 and 11)}

The present day structure of the North Arabian rift basins was finally formed during $12-13 \mathrm{Ma}$, from the late Middle Miocene to Recent. In the Palmyrides the tightly folded Mesozoic-Cainozoic sequence was detached from older rocks by a decollement (Salel and Suguret, 1994; Kopp et al., 1994). A broad swell was formed in the Sinjar trough. 

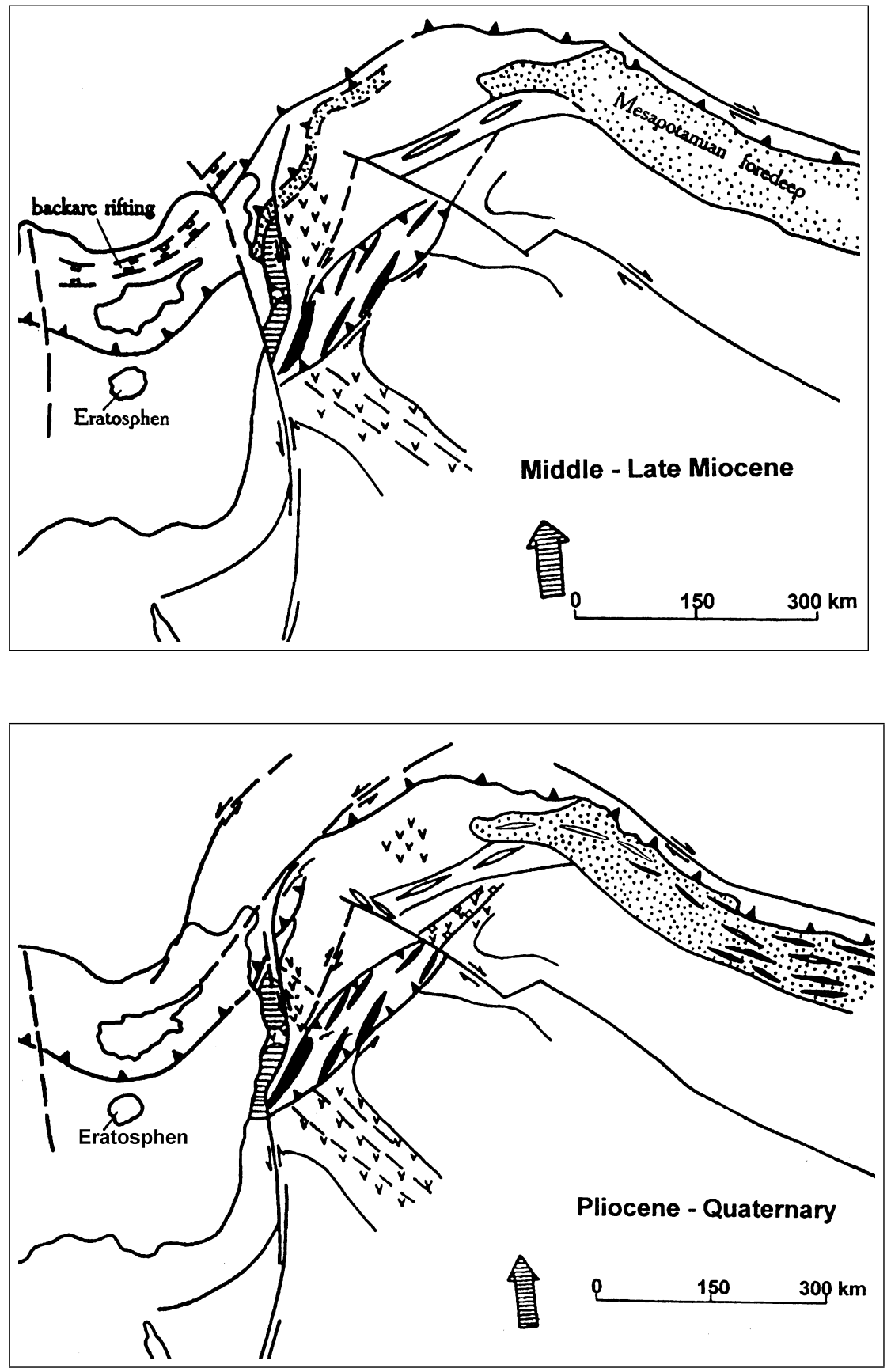

Fig. 10. Paleotectonic scheme for the Middle-Late Miocene. The MioceneQuarternary compression, 1-st phase. Symbols in Fig. 4a.
Fig. 11. Paleotectonic scheme for the Pliocene-Quarternary. The MioceneQuaternary compression, 2-nd phase.
The Euphrates graben and Drouz depression again were not affected by compression. Direction of the deformation axis as determined from the regional structural pattern was NWSE, i.e. nearly parallel to the Euphrates graben and nearly perpendicular to Palmyrides. Folding was not renewed in the late Cretaceous Sinai fold belt.

Activation of deformation in the Palmyrides, Antilebanon and Lebanon was directly related to formation of a new divergent plate boundary in the Gulf of Aden and Red Sea rift about $12 \mathrm{Ma}$ ago (Le Pichon and Gaulier, 1988), the beginning of transform motion along the Dead Sea fault and separation of Arabia from Sinai. The rate of the Arabia mo- tion relative to Eurasia increased from $1 \mathrm{~cm}$ y- 1 to $2.8 \mathrm{~cm}$ y-1 (Savostin et al., 1986; De Metz et al., 1990) which led to intensive nappe formation lateral block expulsion in the collision belt of southeastern Turkey. The zone of maximum intraplate deformation was in western Palmyrides, Antilebanon and Lebanon, where compression was enhanced by a restraining band of the transform boundary (Freund et al., 1970; Yoffe and Garfunkel, 1987; Kopp et al., 1994). Of $105 \mathrm{~km}$ displacement on the Dead Sea fault (Quennel, 1958, 1984; Freund et al., 1970), $20 \mathrm{~km}$ or more were compensated by shortening in the western Palmyrides (Chaimov et al., 1990). The major deformation was apparently related to 


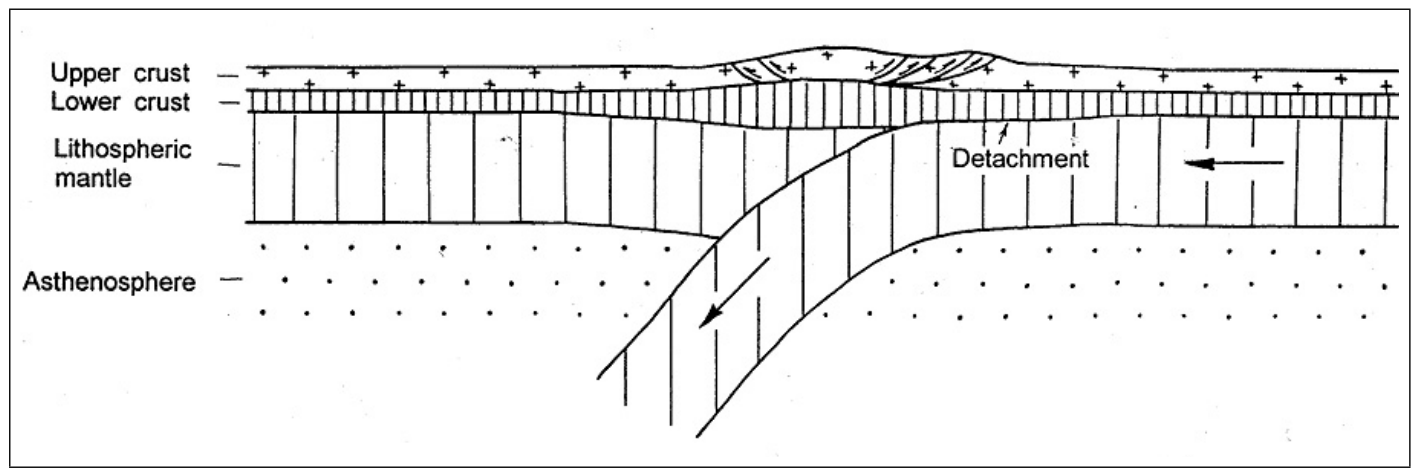

Fig. 12. A model of continent-continent collision (after Lobkovsky, 1988). The lithospheric mantle is detached from the crust and subducted. The duktile lower crust is "pumped" to the collision zone to create a bulge. The upper crust is detached to form a pile of imbricated nappes.

the movement of the block limited by the Dead Sea and Euphrates faults. The Euphrates graben and Drouz depression again were not inverted, the latter showing clear evidence of extension (transtension?) in the form of fractures controlling basaltic eruptions.

Although the causual connection of the intraplate deformation with the plate boundary evolution is apparent, the dynamic aspect of the process remains problematic. What moved Arabia northward in spite of the head-resistance of the collision?

Two explanations seem probable. It is reasonably well established that the origin of the Gulf of Aden, Red Sea and Ethiopian rift triple system was causally related to Afar plume activity (Courtillot et al., 1999). But were the forces induced by this activity sufficient to break up the continental lithosphere and to move plates, especially in the case of Arabia, whose motion was heavily obstructed by the collision with Eurasia? As concluded by Courtillot et al. (1999) "an active component (a plume and resulting flood basalt) is a pre-requisite for the breakup of a major oceanic basin. But rifting must be allowed by plate-boundary forces ..." Note that the initial rifting in the Red Sea and Gulf of Aden and flood basalt eruption around the Afar triple junction occured $30 \mathrm{Ma}$ ago, i.e. when the Arabia - Eurasia collision was already in a full swing and the plate boundary conditions were not favorable for rifting. Moreover, fast opening of the Red Sea and Gulf of Aden began about $12 \mathrm{Ma}$ ago (Le Pichon and Gaulier, 1988), long after the peak of plume activity.

A model of collision by L. Lobkovsky (1988,) suggests another solution of the problem. According to this model the mantle part of the lithosphere is detached in the collision zone from the mid-upper crust along the mechanically weak lower crust and continues to subduct for a few dozens of myr after collision. The detached crust meanwhile is piled up and thickend due to nappe formation, folding and other mechanisms of crustal shortening (Fig. 12). A conspicuous feature of this process is detachment of mid-upper crustal nappes off the subducting plate in a way resembling formation of accretionary prisms. In this way two problems are solved: the problem the driving force that moves plates for a long distance after collision (e.g. Arabia, India) and the problem of space for the lithospheric mantle, which apparently can not be shortened by "crustal" mechanisms.

Following this train of throught, rifting and separation of lithospheric plates in the Gulf of Aden and Red Sea are explained as a result of extension created by a pull of the sinking Arabian lithospheric mantle. The locus of the future rifting was pre-determined by the thermal or thermo-mechanical effect of the plume head and, possibly, by pre-existing zones of weakness. At the same time compression was transmitted at a the crustal level from the collision zone to the interrior of the Arabian plate to produce inversion in the rift basins. Compression was locally enhanced by a restraining bend of the transform boundary between the Arabian and Sinai plates (Freund et al., 1970; Yoffe and Garfunkel, 1987; Kopp et al., 1994).

\section{Conclusion}

The sedimentary basins of North Arabia display a long history of intraplate deformation: rifting and inversion. The major rifting episodes in the Late Carboniferous-Permian, Middle-Late Triassic and late Early Cretaceous were followed by periods of the post-rift subsidence and accumulation of sediments.

Phases of intraplate extension and rifting correlate with major re-organizations of the plate boundaries in the adjacent Tethys ocean. In the Late Carboniferous-Permian and Triassic, several microcontinents were rifted off the Gondwana passive margin. It is speculated here that extension was transmitted from the active margin of the ocean at the time, when the Paleotethyan ridge was subducted and Paleotethys and Gondwana became one plate. Extension generated on the Gondwana margin by the slab pull in the south-facing subduction zone ceased immediately after new spreading centers were formed in Neotethys and Mesogea in the Permian and Late Triassic (?) respectively.

The next, late Early Cretaceous phase of extension and intraplate rifting was again related to the slab pull. At that time north-dipping subduction began in the Peri-Arabian system 
of trenches, from where extension was directly transmitted to the continental part of the plate.

Inversions in the North Arabian rift basins correlate with collisions at the northern margin of the African-Arabian plate. The Campanian-Early Maastrichtian inversion occured at the time of the passive margin collision with the PeriArabian trench system and ophiolite obduction. Compression was evident not not only in North Arabia but also in Sinai and northeast Africa (Syrian arc), which is interpreted to result from the collision of the Cyprus trench with an extended African passive margin. Basin inversions in the Middle Eocene-Oligocene and Neogene-Quaternary reflect stages of the Arabia-Eurasia collision.

To explain simultaneous collision and rifting at the northern and southern boundaries of the Arabian plate respectively, a hypothesis of independent lithospheric mantle subduction in the collision zone is invoked (Lobkovsky, 1988). The pull of sinking lithospheric mantle detached from the crust is considered as a driving force moving a plate during continent-continent collision. This force is assumed to be sufficient to produce extension and rupture in areas of lithospheric weakness (Red Sea) and scrapping off and piling up a crustal material in the Bitlis zone of Southeast Turkey. At the crustal level strong compression was transmitted from the collision zone to intraplate regions. It appears therefore that the slab pull was a major moving force responsible for Mesozoic-Cainozoic rifting and compressional deformation in North Arabia.

\section{References}

Al-Saad, D., Sawaf, T., Gerban, A., Barazangi, M., Best, J. A., and Chaimov, T. A.: Crustal structure of Central Syria: the intracontinental Palmyrides mountain belt, Tectonophysics, 207, 345-358, 1992.

Baroz, F.: Volcanism and continent-island arc collision in the Pentadactylos Range, Cyprus, in: Panayiotou, A. (Ed.): Ophiolites, Proceed. Intern. Ophiol. Symp., Cyprus, 1979, Nicosia: Geol. Surv. Depart., 1980, 73-85, 1980.

Belov, A. A.: Tectonic evolution of the Alpine fold area in the Paleozoic, Moscow, Nauka, 212 p. (in Russian), 1981.

Ben-Menachem, A., Nur, A., and Vered, M.: Tectonics, seismicity and structure of the Afro-Eurasian junction - the breaking of an incoherent plate, Physics of the Earth and Planet. Interriors, 12, 1-50, 1976.

Ben-Menachem, A. and Aboodi, E.: Micro- and macroseismicity of the Dead Sea rift and off-coast eastern Mediterranean, Tectonophysics, 80, 199-234, 1981.

Berberian, M. and King, G. C. P.: Towards a paleogeography and tectonic evolution of Iran, Can. J. Earth. Sci, 18, 210-265, 1981.

Best, J. A., Barazangi, M., Al-Saad, D., Sawaf, T., and Gebran, A.: Bouguer gravity trends and crustal structure of the Palmyride mountain belt and surrounding northern Arabian platform in Syria, Geology, 18, 1235-1239, 1990.

Brew, G. E., Litak, R. K., Seber, D., Barazangi, M., Al-Imam, A., and Sawaf, T.: Basement depth and sedimentary velocity structure in the northern Arabian platform, eastern Syria, Geophys. J. Int., 128, 617-631, 1997.
Burke, K. and Dewey, J. F.: Plume generated tripple junctions: Key indicators on applying plate tectonics to older rocks, J. of Geology, 81, 159-171, 1973.

Campbell, L. H. and Griffits, R. W.: Implication of mantle plume structure for the evolution of flood basalts, Earth and Planet Sci. Lett., 99, 79-93, 1990.

Chaimov, A., Barazangi, M., Al-Saad, D., Sawaf, T., and Gebran, A.: Crustal shortening in the Palmyride fold belt Syria and implications for movement along the Dead Sea Fault System, Tectonics, 9 (6), 1369-1386, 1990.

Chaimov, T. A., Barazangi, M., Al-Saad, D., Sawaf, T., and Gebran, A.: Mesozoic and Cenozoic deformation inferred from seismic stratigraphy in the southwestern intracontinental Palmyride foldthrust belt, Syria, Geol. Soc. of Amer. Bull., 104, 704-715, 1992.

Chaimov, T. A., Barazangi, M., Al-Saad, D., Sawaf, T., and Khaddour, M.: Seismic fabric and 3-D structure of the southwestern intracontinental Palmyride fold belt, Am.Ass. Petr. Geologists Bulletin, 77(12), 2032-2047, 1993.

Cherven, V. B.: Tethys marginal sedimentary basins in western Iran, Geol. Soc. Amer. Bull., 97, 516-522, 1986.

Coffin, M. F. and Eldholm, O. (Eds.): Large Igneous Provinces, JOI/USSAC Workshop Report, The Univ. of Texas at Austin Inst. for Geophisics Rep., N114, 79p, 1991.

Courtillot, V., Jaupart, C., Manighetti, I., Tapponier, P., and Besse, J.: On causual links between flood basalts and continental breakup, Earth and Planet. Sci. Lett., 166, 177-195, 1999.

De Mets, C., Gordon, R. G., Argus, D. F., and Stein, S.: Current plate motions, Geopys. J. International, 101, 425-478, 1990.

Dercourt, J., Zonenshain, L. P., Ricou, L.-E., Kazmin, V. G., Le Pichon, X., Knipper, A. L., Grandjacquet, C., Sbortshikov, I. M., Geyssant, J., Lepvrier, C., Sorochtin, O., Westphal, M., Bazhenov, M., Lauer, J. P., and Biju-Duval, B.: Geological evolution of the Tethys belt from the Atlantic to the Pamir since Lias, Tectonophysics, 123, 241-315, 1986.

Dercout, J., Ricou, L.-E., and Vrielinck, B. (Eds.): Atlas Tethys, paleoenvironmental maps, Gauthier-Villars, Paris, 307p, 1993.

De Wever, P., Bourdillon de-Gissac, Ch., and Bechennec, F.: Permian age from radiolarites of the Hawasina nappes. Oman Mountains, Geology, 16, 912-914, 1988.

Dubertret, L.: Géologie des roches vertes du nord-ouest de la Syrie et du Hatay (Turquie), Théses doct. Sci. natur. Fac.Sci. Univ. Paris, Museum nat. histoire. natur., 226p, 1953.

Faradzhev, V. A.: The geological map of Syria, scale 1:200000, sheet J-37-IV. Explanatory notes, Technoexport, Moscow, 146p, 1966.

Freund, R., Garfunkel, I. Z., Goldberg, M., Weissbrod, T., and Derin, B.: The sheer along the Dead Sea rift, Phil. Trans. Roy. Soc. London, A267, 107-130, 1970.

Galaktionov, A. B. and Demidov, V. A.: Geological map of Syria, scale 1:200 000, sheets J-37- VI, XII. Explanatory notes, Technoexport, Moscow., 83p, 1966.

Garfunkel, Z. and Derin, B.: Permian-early Mesozoic tectonism and continental margin formation in Israel and its implications for the history of the Eastern Mediterranean, in: Dixon, J. E. and Robertson, A. H. F. (Eds.): The geological evolution of the Eastern Mediterranean, Oxford, Blackwell Sci. Publications, 187201, 1984.

Geological map of Cyprus, 1:250 000, Geol. Dep. Cypus, 1979.

Geological map of Syria, 1:1000000. Ponikarov, V. P. and Mikhailov, I. A. (Eds.), Technoexport, Moscow, 1964.

Golonka, J.: Cambrian-Neogene plate tectonic maps.Wydawnictwo Uniwersytetu Jagiellonskiego, Krakow, 125p, 36 plates, 2000. 
Guiraud, R. and Bellon, Y.: Late Carboniferous to recent geodynamic evolution of the West Gondwanian cratonic Tethyan margins, in: Nairn, A. E. M., Ricou, L.-E., Vrielynk, B., and Dercourt, J. (Eds.): The ocean basins and margins. v.8. The Tethys ocean, Plenum press, New York, London, 101-124, 1996.

Guirand, R. and Bosworth, W.: Senonian basin inversion and rejuvenation of rifting in Africa and Arabia: synthesis and implications to plate tectonics, Tectonophysics, 282(1-4), 39-82, 1997.

Hencock, P. L. and Atiya, M. S.: Tectonic significance of mesofracture systems associated with the Lebanese segment of the Dead Sea transform fault, J. of Struct. Geol., 1, 143-153, 1979.

Hill, R. I.: Starting plumes and continental breakup, Earth and Planet. Sci. Lett., 104, 398- 416, 1991.

Hirsh, F.: Apercu de l'histoire phanerozoique d'Israel, J. of African Earth Science, 11 (1-2), 177-196, 1990.

Hooper, P. R.: The timing of crustal extension and eruption of continental flood basalts, Nature, 345, 246-249, 1990.

Illies, J. H.: Intra-plate rifting and the Alpine system, in: Pilger, A. and Rosler, A. (Eds.): Afar depression of Ethiopia, Stuttgart, Schweizerbartsche Verl., 1-10, 1975.

Irving, W. P., Murchey, B. L., Jones, D. L., and Kling, S. A.: MidCretaceous radiolarians in Parapedi formation, Cyprus, Ofioliti, 5 (2-3), p265, 1980.

Joffe, S. and Garfunkel, Z.: Plate kinematics of circum Red Sea - a re-evaluation, Tectonophysics, 141, 5-22, 1987.

Kazmin, V. G.: Formation of the Troodos and Mammonia complexes (Cyprus): tectonic setting, Geotektonika, N6, 104-114 (in Russian), 1991a.

Kazmin, V. G.: Collision and rifting in the Tethys Ocean: geodynamic implications, Tectonophysics, 196, 371-384, $1991 \mathrm{~b}$.

Knipper, A. L., Ricou, 1.-E., and Dercourt, J.: Ophiolites as indicators of the geodynamic evolution of the Tethyan Ocean, Tectonophysics, 123, 213-240, 1986.

Knipper, A. L., Savel'ev, A. A., and Rukie, M.: Ophiolite association of Northwestern Syria, Geotektonika, N1, 92-104 (in Russian), 1988.

Knipper, A. L. and Sharaskin, A. Ya: Tectonic evolution of the western part of the Peri-Arabian ophiolite arc, in: Krasheninnikov, V. A. and Hall, J. K. (Eds): Geological structure of the Northwestern Mediterranean, Jerusalem, 295-305, 1994.

Kopp, M. L., Leonov, Yu. G., and Adjamian, J.: Deformations of the Western Arabian plate as a result of strike slip along the Levant fault, Geotectonika N3, 61-76, (in Russian), 1994.

Kozlov, V. V., Artemov, A. V., and Kalis, A. F.: Geological map of Syria, scale 1:200 000, sheets I-36-XVIII, I-37-XIII. Explanatory notes, Technoexport, Moscow, 68p, 1966.

Krylov, K. A., Silant'ev, S. A., and Krasheninnikov, V. A.: Tectonic structure and evolution of southwestern Cyprus, in: Krasheninnikov, V. A., Hall, J., Hirsch, F., and Benjamini, C. (Eds.): Geology of Near East, (in press), 2002.

Leonov, Yu. G., Makarem, X., and Zaza, T.: To the origin of an olistostroma in the core of the Abd El-Aziz anticline, Geotektonika, N2, 85-81 (in Russian), 1986.

Le Pichon, X. and Gaulier, J.-M.: The rotation of Arabia and the Levant fault system, Tectonophysics, 153, 271-294, 1988.

Lobkovsky L. I.: Geodynamics of spreading and subduction and two-level plate tectonics, Moscow, Nauka, 252p, (in Russian), 1988.

Lovelock, P. E. R.: A review of the tectonics of the northern Middle East region, Geol. Mag., 121(6), 577-587, 1984.

Mc.Bride, J. H., Barazangi, M., Best, J., Al-Saad, D., Sawaf, T., AlOtri, M., and Gerban, A.: Seismic reflection structure of intracra- tonic Palmyride fold-thrust belt and surrounding Arabian platform, Syria, Am.Ass. Petrol. Geol.Bull. 74(3), 238-259, 1990.

Molnar, P. and Tapponier, P.: Cenozoic tectonics of Asia: effects of a continental collision, Science, 189, 419-426, 1975.

Murris, F.: Middle East stratigraphic evolution and oil habitat, Am. Ass. Petroleum Geologist Bull., 64, 597-618, 1980.

Natapov, L. M. and Kazmin, V. G. (Eds.): Paleogeographic Atlas of Northern Eurasia, Institute of Tectonics of Lithospheric Plates, Moscow, 26 maps and Expl. notes, 1998.

Nikishin, A. M., Ziegler, P. A., Stephenson R. A., Cloething, S., Furne, A. V., Fokin, P. A., Ershov, A. V., Bolotov, S. N., Korotaev, M. V., Alekseev, A. S., Gorbachev V. I., Shipilov, E. V., Lankreijer, A. C., Bembinova, E. Yu., and Shalimov, I. V.: Late Precambrian to Triassic history of the East European Craton: dynamics of sedimentary basin evolution, Tectonophysics, 268, 23 63, 1996.

Pan Yusheng (Ed.): Geological evolution of the Karakorum and Kunlun mountains, Seismological Press, Beijing, 288p, 1996.

Parrot, J. F. and Whitechurch, H.: Subductions antérieures au chariage Nord-Sud de la téthysienne: facteur de métamorphisme de séries sédimentaires et volcaniques liées aux assemblages ophiolitiques syro-turcs en schists verts et amphibolites, Rév. Géogr. Phys. Géol. Dynam., 20 (2) 153-170, 1978.

Ponikarov, V. P. and Kazmin, V. G.: Precambrian and Paleozoic deposits in northwestern Arabian peninsula, Sovetskaya Geologiya, N3, 89-99 (in Russian), 1965.

Ponikarov, V. P., Kazmin, V. G., Mikhailov, I. A., Razvalyaev, A. V., Krasheninnikov, V. A., Kozlov, V. V. Soulidi-Kondrat'ev, E. D., Michailov, K. Ya, Kulakov, V. V. Faradzhev, V. A., and Mirzaev, K. M.: The geology of Syria. Part 1. Stratigraphy, igneous rocks and tectonics, Ministry of Geol., USSR, Technoexport, 230p, 1967.

Ponikarov, V. P., Kazmin, V. G., Kozlov, V. V. Krasheninnikov, V. A., Mikhailov, I. A., Razvalyaev, A. V., Soulidi-Kondrat'ev, E. D., Ouflyand, A. K., and Faradzhev, V. A.: Syria. Geology and mineral resources of foreign countries, V.14, Leningrad, Nedra, 216p, (in Russian), 1968.

Ponomarev, B. Ya. and Bivshev, A. S.: Geological map of Syria, 1:200 000, sheet J-37-IV. Explanatory notes, Technoexport, Moscow, 66p, 1966.

Quennel, A. M.: The structure and geomorphic evolution of the Dead Sea rift, Quarterly Journal of the Ecological Society of London, 114, 1-24, 1958.

Quennell, A. M.: The Western Arabia rift system, in: Dixon, J. E. and Robertson, A.H.T. (Eds.): The geological evolution of the Eastern Mediterranean, Geol. Soc. London, Special Publ., Blackwell, London, 775-788, 1984.

Razvalyaev, A. V.: Geological map of Syria, 1:200 000, sheet I-37VIII. Explanatory notes, Technoexport, Moscow. 124p, 1966.

Robertson, A.H.F. and Woodcock, N. H.: Mamonia Complex, southwest Cyprus: Evolution, and emplacement of a Mesozoic continental margin, Geol. Soc. Amer. Bull., 90, 651-665, 1979.

Robertson, A.H.F. and Woodcock, N. H.: Tectonic setting of the Troodos massif in the East Mediterranean. Ophiolites, Proceed. Intern. ophiol. Symp. Cyprus, 1979, Nicosia: Geol.Surv. Depart., 36-49, 1980

Robertson, A.H.F., Dixon, J. E., Brown, S., Collins, A., Morris, A., Pickett, E. A., Sharp, I., and Ustaomer, T.: Alternative tectonic models for the Late Paleozoic-Early Tertiary development of Tethys in the Eastern Mediterranean region, in: Morris, A. and Tarling, O. H. (Eds): Paleomagnetism and tectonics of the Mediterranean region, Geol. Soc. London, Special Publications, 
105, 239-263, 1996.

Ruttner, A. W.: The Pre-Liassic basement of the Eastern Kopet Dagh Range, N. Jb. Geol. Palaont., Abh. 168, 2/3, 256-268, 1984.

Salel, J. F. and Siguret, M.: Late Cretaceous to Paleogene thinskinned tectonics of the Palmyrides belt (Syria), Tectonophysics, 234, 265-290, 1994.

Savostin, L. A., Sibuet, J.-C., Zonenshain, L. P., Le Pichon, X., and Roulet, M. J.: Kinematic evolution of the Tethys belt from the Atlantic Ocean to the Pamirs since the Triassic, Tectonophysics, 123, 1-35, 1986.

Sawaf, T., Al-Saad, D., Gebran, A., Barazangi, M., Best, J. A., and Chaimov, T. A.: Stratigraphy and structure of eastern Syria across the Euphrates depression, Tectonophysics, 220, 267-281, 1993.

Segev, A.: Synchronous magmatic cycles during the fragmentation of Gondwana: radiometric ages from Levant and other provinces, Tectonophysics, 325, 257-277, 2000.

Sengor, A. M. C.: Mid-Mesozoic closure of Permo-Triassic Tethys and its implications, Nature, 29, 590-593, 1979.

Sengor, A. M. C.: The Cimmeride orogenic system and the tectonics of Eurasia, Geol. Soc. Am. Spec. Paper, 195, 82p, 1984.

Sengor, A. M.C.: A new model for the late Paleozoic-Mesozoic tectonic evolution of Iran and implications for Oman, Geol.Soc. London, Spec. Publ., 49, 797-831, 1990.

Sengor, A. M.C. and Yilmaz, Yu.: Tethyan evolution of Turkey: a plate tectonic approach, Tectonophysics, 75, 181-241, 1981.

Sengor, A. M. C., Cin, A., Rowley, D. B., and Shangyou, N.: Magmatic evolution of Tethysides: a guide to reconstruction of collage history, Palaeogeography, Palaeoclimatopogy, Palaeoecology, 87, 411-440, 1991.

Saulidi - Kondrat'ev, E. D.: The geological map of Syria, 1:200000, sheet 1-37-XV. Explanatory notes, Technoexport,
Moscow, 104, 1966.

Stampfli, G., Marcoux, J., and Baud, A.: Tethyan margins in space and time, in: Channel, J. E. T., Winterer, E. L., and Jansa, L. F. (Eds.): Paleogeoraphy and paleooceanography of Tethys, Palaeogeography, Palaeoclimatology, Palaeoecology, 87, 373410, 1991.

Stampfli, G. M. and Pillevuit, A.: An alternative Permo-Triassic reconstruction of the kinematics of the Tethyan realm, in: Dercourt, J., Ricou, L.-E., and Vrielinck, B. (Eds.): Atlas Tethys. Palaeoenvironmental Maps. Explanatory notes, Gauthier-Villars, Paris, 55-62, 1993.

Stampfli, G. M. and Mosar, J.: The Plate Tectonics of the Western Tethyan Regions. 6th Zonenshain Conf. on Plate Tectonics. Programme \& Abstracts, Inst. Oceanology RAS and Geomar, Moscow, 132-133, 1998.

Shwolman V. A.: Tectonic evolution of the Pamirs in the Cretaceous and Paleogene, Nedra, Moscow, 159p, (in Russian), 1977.

White, R. S. and McKenzie, D.: Magmatism at rift zones: the generation of volcanic continental margins and flood basalts, Geophys. Res., 94, 7685-7729, 1989.

White, R. S. and McKenzie, D.: Mantle plumes and flood basalts, J. Geophys. Res., 100, 17 543-17 585, 1995.

Yazgan, E.: Geodynamic evolution of the Eastern Taurus region, in: Tekeli, O. and Goncuoglu, M. C. (Eds.): Geology of the Taurus Belt, MTA, Ankara, 199-208, 1984.

Ziegler, P. A.: Geological Atlas of Western and Central Europe. 2nd edition, Shell Intern. Petroleum Maatschappij B. V., 239p and 56 enclosures, 1990.

Zoback, M. L. and Zoback, M. D.: Global pattern of tectonic stress, Nature, 341, 291-298, 1989.

Zonenshain, L. P. and Savostin, L. A.: Geodynamics of the Baikal rift zone and plate tectonics of Asia, Tectonophysics, 76, 1-45, 1981. 